GLOSSARY

\title{
Embodiment: a conceptual glossary for epidemiology
}

\author{
Nancy Krieger
}

J Epidemiol Community Health 2005;59:350-355. doi: 10.1136/jech.2004.024562

Embodiment. This construct and process are central to ecosocial theory and epidemiological inquiry. Recognising that we, as humans, are simultaneously social beings and biological organisms, the notion of "embodiment" advances three critical claims: (1) bodies tell stories about-and cannot be studied divorced from - the conditions of our existence; (2) bodies tell stories that often-but not always - match people's stated accounts; and (3) bodies tell stories that people cannot or will not tell, either because they are unable, forbidden, or choose not to tell. Just as the proverbial "dead man's bones" do in fact tell tales, via forensic pathology and historical anthropometry, so too do our living bodies tell stories about our lives, whether or not these are ever consciously expressed. This glossary sketches some key concepts, definitions, and hypotheses relevant for using the construct of "embodiment" in epidemiological research, so as to promote not only rigorous science but also social equity in health.

\footnotetext{
Correspondence to:

Professor N Krieger,

Department of Society,

Human Development and

Health, Harvard School of

Public Health, Kresge 717,

677 Huntington Avenue,

Boston, MA 02115, USA;

nkrieger@hsph.harvard.

edu
}

Accepted for publication 5 July 2004 support for childcare; universal sanitation and sustainable development; safe workplaces and healthy cities; universal health care and immunisations; and the protection and promotion of human rights-economic, social, political, civil, and cultural. As has long been argued, although not always widely appreciated, it is no accident that from population patterns of health, disease, and wellbeing it is possible to discern the contours and distribution of power, property, and technology within and across nations, over time. ${ }^{1-14}$ Or, more pointedly, from the conditions of our bodies-and those of the animals and plants whose environs we now shape-you can gain deep insight into the workings of the body politic.

Embodiment, in other words, is literal. ${ }^{1-4}$ The ecosocial premise is that clues to current and changing population patterns of health, including social disparities in health, are to be found chiefly in the dynamic social, material, and ecological contexts into which we are born, develop, interact, and endeavour to live meaningful lives. The contrast is to pervasive aetiological hypotheses concerned mainly with decontextualised and disembodied "behaviours" and "exposures" interacting with equally decontextualised and disembodied "genes." The distinction is more than simply between "determinants" and "mechanisms." Consider, for example, contending-and longstandingclaims about racism compared with "race" as causes of racial/ethnic disparities in health. ${ }^{1-3}$ 15-22 An embodied approach promotes testing hypotheses to ascertain if the observed disparities are a biological expression of racial discrimination, past and present; by contrast, a disembodied and decontextualised approach promulgates research focused on detrimental genes and/or "lifestyles."15-22 The vastly different implications of these approaches for generating epidemiological knowledge and informing policy underscore the utility of clarifying the significance of "embodiment" for epidemiological inquiry.

In this glossary, I accordingly sketch some key concepts, definitions, and hypotheses relevant for using the construct of "embodiment" in epidemiological research. These entries necessarily draw on scholarship from a variety of disciplines, including not only epidemiology and public health more generally, but also additional social and biological sciences that likewise have longstanding interest in bodies and their genesis, comportment, and wellbeing..$^{5-10}{ }^{23-37}$ In the case of epidemiology, the discipline specific challenge is to grapple with the implications of "embodiment" for developing and testing apt hypotheses about why and how historically contingent, spatial, temporal, and multilevel processes 
become embodied and generate population patterns of health, disease, and wellbeing, including social inequalities in health. This work necessarily entails concretely measuring population rates, biological characteristics, diagnostic criteria, disease states, and myriad social, physical, chemical, and biological exposures thought to be relevant to shaping risk of the specified outcomes. The hope is that by systematically conceptualising this work in relation to "embodiment," it will be possible to promote not only more rigorous science but also enhanced knowledge relevant to attaining social equity in health.

\section{EMBODIMENT: EPIDEMIOLOGICAL NOTIONS (a) As a construct, process, and reality, contingent upon bodily existence}

Embodiment is a verb-like noun that expresses an abstract idea, a process, and concrete reality. Whether used literally or figuratively, ${ }^{38}$ it insists on bodies as active and engaged entities.

In the case of epidemiology, at the most general level, embodiment, as an idea, refers to how we, like any living organism, literally incorporate, biologically, the world in which we live, including our societal and ecological circumstances. ${ }^{1-3}$ From an epidemiological vantage concerned with population health, this world is comprised of animate populations and inanimate entities interacting at multiple scales and levels in myriad ecosystems that have evolved over time, with the living beings actively shaping and not simply passively responding to their environs. ${ }^{1-3}{ }^{14}{ }^{23-37}$ Embodiment, for epidemiology, thus entails consideration of more than simply "phenotypes," "genotypes," and a vaguely defined (and implicitly external) "environment" eliciting "geneenvironment" interactions. We live embodied: "genes" do not interact with exogenous (that is, outside of the body) environments-only organisms do, with consequences for gene regulation and expression. ${ }^{42-35}$ 39-42

As such, embodiment necessarily is a process, for it entails the temporal transformation of bodily characteristics as a consequence of animate beings' terms of engagement in their world. While much of this engagement may entail conscious choices and thus agency, it need not always be a "conscious" process or necessarily involve psychosocial "risk factors." Thus, tobacco firms may excel at marketing cigarettes simultaneously as a symbol of "independence" (and often, "masculinity"), as a "luxury" to people with limited economic resources, and as a kind of "affirmation" of existence to socially marginalised groups, such as African Americans and also lesbian, gay, bisexual and transgender youth. ${ }^{43}$ Choices of tobacco marketing executives thus influence the responses of these groups to pervasive and targeted advertising, as do the psychoactive properties of nicotine in alleviating stress. Even so, the physiological processes by which nicotine induces nicotine dependence at a cellular level are not, in itself, conscious. Related, an infant is not conscious of its birth weight or gestational age, even as both may be relevant to infant and adult health. ${ }^{45-47}$ Bodies thus bear the mark of both conscious and unconscious processes.

The concrete reality of embodiment in turn is expressed in biological characteristics, which exhibit both individual and population distributions, and which overwhelmingly are the outcomes epidemiologists measure. These characteristics can range from macroscopic (for example, waist to hip ratio) to microscopic (for example, gene expression); their measurement depends both on scientific creativity and available technology. ${ }^{4}$ Whether these embodied biological characteristics shape subsequent health status depends on the characteristic's expression and also relevance to one or several health outcomes, which can include bodily illness, mental illness, disability, or death. Waist to hip ratio, for example, exhibits variability within both individuals and populations, with higher ratios associated with increased risk of morbidity and mortality. ${ }^{48-50}$ The impact of a high ratio, moreover, is not a function simply of relative distribution within a population: in a region or country with a high average waist to hip ratio, even a ratio below average can still be pathogenic. Related, taking embodiment seriously as a process and reality can help ensure that measured differences in biological characteristics across populations, whether waist to hip ratio or disease rates, are not immediately assumed to reflect innate biological differences; instead, it encourages asking what might be different about the populations' societal contexts that in turn is expressed in their bodily characteristics.

Finally, while perhaps obvious, embodiment is contingent upon having a body. Understanding probable pathways of embodiment thus requires clarity about what it is that bodies do, as jointly biological organisms and social beings. Minimally, this includes, as elaborated in table $2^{4}$ :

(a) for biological organism: reproduce; develop; grow; interact; exist in time and space; and evolve;

(b) for social being: societal context; social position; social production; social consumption; and social reproduction.

Consideration of these integral aspects of bodily existence is key for understanding both population health and social inequalities in health. ${ }^{1-4} 47$

(b) As a multilevel phenomenon, integrating soma, psyche, and society, within historical and ecological context, and hence an antonym to disembodied genes, minds, and behaviours

Embodiment is, by definition, a multilevel phenomenon, as it necessarily entails the interplay between bodies, components of bodies, and the world(s) in which the bodies live. As observed by the biologist Steven Rose, when a frog jumps into a pond to avoid being eaten by a snake, it is a unitary phenomenon, resulting in a safe frog and disappointed snake, even as it can be analysed in relation to many levels (pages 10-13). ${ }^{42}$ Among these levels are: micro phenomena within the body, for example, the physiology of sight, the biochemistry of muscle cell contraction; macro phenomena, for example, the evolution of ecosystems including both frogs and snakes; and meso phenomena, for example, the factors leading to that particular frog being hunted by that particular snake on that particular day. Embodiment, as a construct, usefully invites considering connections between these different levels when developing explanations at any particular level.

Analysing embodiment of social conditions accordingly requires specifying both the social conditions and the biological processes by which they are embodied. These social conditions may be manifested in physical, chemical, biological, or social exposures. Their biological impact in turn will depend on biological characteristics of exposed body. These characteristics may themselves often be shaped by exogenous exposures and cannot simply be inferred from gene frequencies..$^{20-22}$ 32-35 39-42 For example, among many species of fish and reptiles, environmental and social conditions, not chromosomal complement, determine biological sex: depending in some cases on temperature and in others on the presence and behaviours of members of its species, the same organism can develop into either a biological male or female. ${ }^{39}$ New research from the fast growing field linking evolutionary and developmental biology likewise is finding that gene function may depend on gene location, for example, in type of cell or type of developmental 
Table 1 Core constructs of ecosocial theory ${ }^{1-3}$

\begin{tabular}{|c|c|}
\hline Construct & Elaboration \\
\hline Embodiment & $\begin{array}{l}\text { a concept referring to how we literally incorporate, biologically, the material and social world in which we live, from in utero to death; a } \\
\text { corollary is that no aspect of our biology can be understood in the absence of knowledge of history and individual and societal ways of } \\
\text { living. } \\
\text { As elaborated in this article, "embodiment" for epidemiology is best understood: } \\
\text { (a) As a construct, process, and reality, contingent upon bodily existence; } \\
\text { (b) As a multilevel phenomenon, integrating soma, psyche, and society, within historical and ecological context, and hence an antonym } \\
\text { to disembodied genes, minds, and behaviours; } \\
\text { (c) As a clue to life histories, hidden and revealed; and } \\
\text { (d) As a reminder of entangled consequences of diverse forms of social inequality. }\end{array}$ \\
\hline Pathways of embodiment & $\begin{array}{l}\text { structured simultaneously by (a) societal arrangements of power, property, and contingent patterns of production, consumption, and } \\
\text { reproduction, and (b) constraints and possibilities of our biology, as shaped by our species' evolutionary history, our ecological context, } \\
\text { and individual histories - that is, trajectories of biological and social development. }\end{array}$ \\
\hline $\begin{array}{l}\text { Cumulative interplay } \\
\text { between exposure, } \\
\text { susceptibility and } \\
\text { resistance }\end{array}$ & $\begin{array}{l}\text { expressed in pathways of embodiment, with each factor and its distribution conceptualised at multiple levels (individual, } \\
\text { neighbourhood, regional, or political jurisdiction, national, inter-national or supra-national) and in multiple domains (for example, } \\
\text { home, work, school, other public settings), in relation to relevant ecological niches, and manifested in processes at multiple scales of time } \\
\text { and space. }\end{array}$ \\
\hline $\begin{array}{l}\text { Accountability } \\
\text { and agency }\end{array}$ & $\begin{array}{l}\text { expressed in pathways of and knowledge about embodiment, in relation to institutions (government, business, and public sector), } \\
\text { communities, households, and individuals, and also to accountability and agency of epidemiologists and other scientists for theories } \\
\text { used and ignored to explain social inequalities in health; a corollary is that, given probable complementary causal explanations at } \\
\text { different scales and levels, epidemiological studies should explicitly name and consider the benefits and limitations of their particular } \\
\text { scale and level of analysis. }\end{array}$ \\
\hline
\end{tabular}

pathway ${ }^{33-35} 40-42$ : as noted by Scott F Gilbert, the gene encoding gylocogen synthase kinase-3 (GSK-3) can be considered a "structural" gene (regulating gylcosis) or a "developmental" gene (affecting neural axis development) depending on tissue location (page 187), ${ }^{35}$ (page 161) ${ }^{40}$ ). Thus, as leading biologists, geneticists, and philosophers and historians of biology have argued, ${ }^{32-35}$ 39-42 the study of biology, especially at the molecular level, would be aided by moving from a disembodied to embodied biology, in context.

A related literature is likewise encouraging moving from a disembodied to embodied study of human culture, cognition, behaviour, and emotion ${ }^{23-33}$-all aspects of being that have a profound bearing on how we live in our bodies and hence our health. Our use of language, consumption of food, sexual practices and identities, types of recreation, use of psychoactive substances, use and experience of violence, and our experience of emotion: all of these are contingent upon and affect bodily practices, in ways that vary by social conventions and economic resources. ${ }^{23-29}$ The construct of embodiment is thus a useful antonym to notions of disembodied genes, minds, and behaviours. The implication, for epidemiology, is that our explanations of population health will necessarily be incomplete if we focus on one level only, whether micro, macro, or meso; embodiment requires a more integrated approach.

Table 2 Selected defining aspects of bodies, as jointly biological organisms and social beings ${ }^{4}$

\begin{tabular}{|c|c|}
\hline Body aspect & Features \\
\hline \multirow[t]{6}{*}{$\begin{array}{l}\text { (1) as biological } \\
\text { organism and member } \\
\text { of a biological species }\end{array}$} & $\begin{array}{l}\text { REPRODUCE: capacity to give rise to the next generation, whether asexually (typically the case for bacteria, the most common form of life on } \\
\text { Earth) or sexually (involving contribution of genetic information from both biological parents), even if not every organism itself } \\
\text { reproduces. }\end{array}$ \\
\hline & DEVELOP: life history change within an organism, involving generation of cellular diversity, differentiation, and morphogenesis. \\
\hline & $\begin{array}{l}\text { GROW: increase in physical size; in multicellular organisms, by processes involving regulation of cell division, addition of new cells (by } \\
\text { mitosis), and deletion of extant cells (by apoptosis). }\end{array}$ \\
\hline & $\begin{array}{l}\text { INTERACT: with other members of species (in deme), with other organisms in same ecosystem, and with the physical environment(s) in which } \\
\text { the ecosystem is located, so as to meet basic needs for food, safety, pleasure, procreation, and rest, including avoiding noxious stimuli, } \\
\text { seeking life sustaining environs, plus reproducing. }\end{array}$ \\
\hline & $\begin{array}{l}\text { EXIST IN TIME AND SPACE: from birth until death, bodies exist (and, if motile, move around) in spatially and temporally delimited ecosystems, } \\
\text { with geographically contingent patterns of temperature, climate (if on land), altitude, and diurnal change (periods of light and dark). }\end{array}$ \\
\hline & $\begin{array}{l}\text { EVOLVE: given key criteria of reproduction, inheritance, and genetic variation, evolution involves emergence of new traits and new species, } \\
\text { reflecting possibilities enabled and constrained through historically contingent biological processes that are "selected" or "filtered" in a } \\
\text { context of changed environments. }\end{array}$ \\
\hline
\end{tabular}

(2) as social being and SOCIETAL CONTEXT: live life in the society (or societies) of which one is a member, vis a vis historical period, economy, political and legal member of society system, technology, and social, cultural, civil, economic and political rights, resources, relationships and institutions, plus location in the global economy and global institutions of governance.

SOCIAL POSITION: born into and/or raised in, and later form, what type of family and/or household, vis a vis social relations of class, gender, sexuality, race/ethnicity, and other salient social divisions premised on power, property, and social inequality.

SOCIAL PRODUCTION: engaged in socially delimited processes, relationships, and institutions, contingent on one's social position, involving production, exchange, distribution and consumption of goods and services, and also ideas and information, with differential distribution and intergenerational transfer of assets typically enforced by law.

SOCIAL CONSUMPTION: engaged in socially delimited processes, relationships, and institutions, contingent on one's social position, involving acquisition and consumption of goods, services, and ideas and information required to meet basic needs (for physical survival) and social needs (for a socially meaningful life).

SOCIAL REPRODUCTION: SOcially delimited processes that sustain, modify, or replace societal structures, relationships, and institutions. 


\section{(c) As clue to life histories, hidden and revealed}

Embodiment is the reason we are able to discern critical aspects of the conditions of people's lives from the state of their bodies, both dead and alive. By considering the stories bodies tell, it is possible to overcome limits imposed by what people are able or willing to recount.

In the case of the dead and prior generations, embodiment leads us to consider what features of social conditions can be discerned from bones and teeth, from records of births and deaths, as well as from written medical records and autopsy results, if available. Historical anthropometry and demography, for example, with their analyses of changing distributions of height and life expectancy, have yielded important insights into the standard of living afforded different populations in prior eras, including diet and conditions of work. $^{5-7}$ Reaching back even further, paleoarcheology has likewise provided valuable evidence regarding conditions of life - and death - in prehistoric times. ${ }^{7}$ That analyses based on such records cannot be corroborated-or refuted-by the deceased person is rarely, if ever, treated as problematic, precisely because of the credence given to recorded anatomical and physiological characteristics. Like any data, however, such embodied evidence can be compromised by various forms of measurement error and bias, including selection bias because of reliance on non-random "convenience" samples, in contrast with population based data. ${ }^{5-7}$

In the case of the living, embodiment likewise invites considering the stories bodies tell in conjunction with those recounted - or hidden or denied-by individuals. One reason, among many, for the profound impact of Kemp's 1962 paper on "The battered child syndrome" ${ }^{\text {"51 }}$ was that it focused on bodily evidence of injuries among infants and children incompatible with self injury, while instead consistent with use of force by an adult against a child. As in the case of domestic violence, despite manifest evidence of such injuries in both the contemporary or historical record, verbal records were weighted towards perpetrators' accounts, because victims often feared to or, in the case of infants, were unable to, testify or have their word be taken seriously. ${ }^{16}{ }^{51-54}$ Embodied evidence has proved to be key in bringing attention to the myriad harms, not only physical but psychological, caused by familial and other forms of interpersonal violence. ${ }^{16} 51-56$

Conversely, bodies can also provide evidence that puts self report and other accounts in context. For example, measures of biomarkers for exposures can be compared with self report measures of exposure. Along these lines, research on serum cotinine compared with self reports of smoking has shown high correlations among smokers, coupled with some misclassification of occasional and infrequent smokers, with little systematic bias by socioeconomic position. ${ }^{5758}$ By contrast, studies comparing self reported with measured height and weight have found evidence of systematic bias by socioeconomic position, with some studies finding a greater-and others a lesser-tendency of persons with more compared with fewer socioeconomic resources to inflate their height and underreport their weight..$^{59}{ }^{60}$ Research on self reported compared with measured food intake has likewise provided evidence of systematic bias, in part reflecting a link between increasing education and a greater concern for socially acceptable responses. ${ }^{61}$

Related, bodily evidence can put in perspective claims about societal impacts of inequality advanced by those benefiting from the status quo. For example, during the US economic depression of the 1930s, economic conservatives claimed the absence of any dramatic change in mortality rates proved conditions were not as bad as economic liberals alleged; countering these claims, Edgar Sydenstricker, the first statistician at the US Public Health Service, argued that the impact would first be seen in morbidity, not mortality, given the difference in aetiological period-and he then marshalled the evidence to prove his point, by establishing a 10 city study of the health impact of the depression that set the basis for what would eventually become the US National Health Interview Survey. ${ }^{62-66}$ More recently, US research linking self reports of racial discrimination to somatic and mental health has recorded adverse effects for people of colour, but not for white Americans reporting "reverse discrimination," thereby hinting at differences of the health impact of long term compared with sporadic instances of unfair treatment. ${ }^{17-19}$ 67-69

\section{(d) As reminder of entangled consequences of diverse forms of social inequality}

Embodiment integrates experience in still one more way highly pertinent to epidemiological inquiry: it reminds us we cannot neatly parse either our social experience or their cumulative impacts on any one or several disease processes. In particular, it highlights the strong likelihood of socially patterned confounding affecting study of exposure-outcome associations in observational studies. ${ }^{470}$ In this kind of research, the construct of embodiment can importantly assist in specifying apt covariates and in interpreting results. ${ }^{1-4}$ For example, considering the public health problem of increased risk of hypertension in African Americans compared with white Americans, "embodiment" reminds us that a person is not one day African American, another day born low birth weight, another day raised in a home bearing remnants of lead paint, another day subjected to racial discrimination at work (and in a job that does not provide health insurance), and still another day living in a racially segregated neighbourhood without a supermarket but with many fast food restaurants. ${ }^{1-4}$ 16-19 71-80 The body does not neatly partition these experiences-all of which may serve to increase risk of uncontrolled hypertension, and some of which may likewise lead to comorbidity, for example, diabetes, thereby further worsening health status. ${ }^{416-19}$ 71-80 To tease out whether and which of these factors are relevant to (or confound) the chosen health outcome under study thus requires conceptualising confounding in relation to embodied consequences of social position.

Indeed, failure to take embodiment seriously can lead to epidemiological research inadvertently increasing, not decreasing, morbidity and mortality. Consider only the current controversy over long term use of hormone replacement therapy (HRT), whereby a recognised and non-trivial increase in risk for breast and endometrial cancer was discounted in favour of claims of preventive benefits for cardiovascular disease. ${ }^{81-85}$ Despite epidemiological evidence published since the 1970s showing the existence of a powerful "healthy user" effect, whereby women who were prescribed and could afford HRT were healthier than the typically less affluent and less healthy women who could not, ${ }^{81} 8286-89$ claims of cardiovascular benefits were and continue to be touted with little regard for how socially patterned confounding affects likelihood of both use of HRT and cardiovascular risk. ${ }^{84} 9091 \mathrm{Had}$ a concern for embodiment and its implications for the social patterning of health been more central to epidemiological research, perhaps epidemiologists would have less readily accepted the biomedical definition of menopause as a disease of "estrogen deficiency" $^{\prime \prime 1}$ and would have sooner curtailed-rather than abetted-widespread iatrogenic use of hormones among healthy women. ${ }^{81-83}$ 87-89

In summary, the construct of embodiment is vital for epidemiology. This is as true for studies concerned with elucidating micro-level factors influencing risk of disease as it is for macro-level studies concerned with explaining temporal 
and spatial contrasts of population rates of morbidity and mortality, including social inequalities in health. The domain of study of our field-determinants and deterrents of population rates of disease, disability, death, and health ${ }^{92}$ necessarily requires us to study people in context. ${ }^{1-4}$ Ultimately, it is by embodying this context that we manifest the observed population patterns of health, disease, and wellbeing, hence the rationale for making study of embodiment a central concern.

\section{REFERENCES}

1 Krieger $\mathrm{N}$. Theories for social epidemiology in the 21 st century: an ecosocial perspective. Int J Epidemiol 2001;30:668-77.

2 Krieger N, ed. Embodying inequality: epidemiologic perspectives. Amityville, NY: Baywood Publishing, 2004.

3 Krieger N. Epidemiology and the web of causation: has anyone seen the spider? Soc Sci Med 1994;39:887-903.

4 Krieger N, Davey Smith G. "Bodies count," and body counts: social epidemiology and embodying inequality. Epidemiol Rev 2004:26:92-103.

5 Steckel RH, Floud R. Health and welfare during industrialization. Chicago: University of Chicago Press, 1997

6 Kolmos J, ed. Stature, living standards, and economic development: essays in anthropometric history. Chicago, IL: University of Chicago Press, 1994.

7 Cohen MN. Health and the rise of nations. New Haven, CT: Yale University Press, 1989.

8 Sydenstricker E. Health and environment. New York: McGraw-Hill, 1933

9 Sigerist HE. Health. J Public Health Policy. 1996; 17: 204-234 (reprinted from, Sigerist HE. Medicine and human welfare. New Haven, CT: Yale University Press, 1941)

10 Rosen G. A history of public health, (1958).Introduction by Elizabeth Fee; bibliographical essay and new bibliography by Edward T Morman. Expanded edtion. Baltimore, MD: Johns Hopkins University Press, 1993.

11 Morris JN. Uses of epidemiology. 3rd ed. Edinburgh: Churchill Livingston, 1975.

12 Susser M. Epidemiology, health, and society: selected papers. New York: Oxford University Press, 1987

13 Terris $M$. The epidemiologic tradition: the Wade Hampton Frost Lecture. Public Health Rep 1979;94:203-9.

14 McMichael T. Human frontiers, environments and disease: Past patterns, uncertain futures. Cambridge: Cambridge University Press, 2001

15 Krieger N. Shades of difference: theoretical underpinnings of the medical controversy on black/white differences in the United States, 1830-1870. Int J Health Serv 1987; 17:259-78.

16 Krieger N. Does racism harm health? Did child abuse exist before 1962? on explicit questions, critical science, and current controversies: an ecosocia perspective, Am J Public Health 2003;93:194-9.

17 Krieger N, Rowley DL, Herman AA, et al. Racism, sexism, and social class: implications for studies of health, disease, and well-being. Am J Prev Med 1993;9(suppl):82-122.

18 Williams DR, Neighbors HW, Jackson JS. Racial/ethnic discrimination and health: findings from community studies. Am J Public Health 2003:93:200-8

19 Clark R, Anderson NB, Clark VR, et al. Racism as a stressor for African Americans: a biopsychosocial model. Am Psychol 1999;54:805-16.

20 Goodman AH. Why genes don't count (for racial differences in health) Am J Public Health 2000;90:1699-702.

21 Cruickshank JK, Mbanya JC, Wilks R, et al. Sick genes, sick individuals or sick populations with chronic disease? The emergence of diabetes and high blood pressure in African-origin populations. Int J Epidemiol 2001;30:111-17.

22 Pearce N, Foliaki S, Sporle A, et al. Genetics, race, ethnicity, and health. BMJ 2004;328:1070-2

23 Scheper-Hughes $\mathbf{N}$, Lock MM. The mindful body: a prolegomenon to future work in medical anthropology. Med Anthropol Q 1987;1:6-41.

24 Weiss G, Haber HF, eds. Perspectives on embodiment: the intersections of nature and culture. New York: Routledge, 1999.

25 Csordas TJ. Body: Anthropological aspects. In: Smelser NJ, Baltes PB, eds. International encyclopedia of the social and behavioral sciences. Elsevier Sciences, 2002, 1270-4. http://www. sciencedirect.com.ezpl harvard.edu/ science/referenceworks/0080430767 (accessed 11 Apr 2004).

26 Tanner J. Body, History of. In: Smelser NJ, Baltes PB, eds. International encyclopedia of the social and behavioral sciences. Elsevier Sciences, 2002, 1277-82. http://www.sciencedirect.com.ezpl .harvard.edu/science/ referenceworks/0080430767 (accessed 11 Apr 2004)

27 Bourdieu P. Distinction: a social critique of the judgment of taste. London: Routledge and Kegan Paul, 1984.

28 Lakoff G. Philosophy in the flesh: the embodied mind and its challenge to Western thought. New York: Basic Books, 1999.

29 Damasio A. Looking for Spinoza: joy, sorrow and the feeling brain. Orlando, FL: Harcourt, 2003.

30 Merleau-Ponty M. Phenomenology of perception. London: Routledge, 2002.

31 Gibson JJ. The ecological approach to visual perception. Boston: HoughtonMifflin, 1979

32 Auxier RE, Edwin LE, eds. The philosophy of Marjorie Grene. Chicago, IL: Open Court, 2002.

33 Eldredge N, Grene M. Interactions: the biological context of social systems. New York: Columbia University Press, 1992.

34 Keller EF. The century of the gene. Cambridge, MA: Harvard University Press, 2000.
35 Buerton PJ, Falk R, Rheinberger $\mathrm{H}-\mathrm{J}$, eds. The concept of the gene in development and evolution: historical and epistemological perspectives. Cambridge: Cambridge University Press, 2000

36 Haraway D. Simians, cyborgs, and women: the reinvention of nature. New York: Routledge, 1991.

37 O'Donovan-Anderson M, ed. The incorporated self: interdisciplinary perspectives on embodiment. Lanham: Rowman and Littlefield, 1996.

38 Oxford University Press. Oxford English Dictionary. 2nd ed.1989 http:// dictionary.oed.com.ezp2.harvard.edu (accessed 11 Apr 2004).

39 Crews D. Sex determination: where environment and genetics meet. Evolution and Development 2003;5:50-5.

40 Gilbert SL. Developmental biology. 7th ed. Sunderland, MA: Sinauer, 2003

41 Lewontin R. The triple helix: gene, organism, and environment. Cambridge, MA: Harvard University Press, 2000.

42 Rose S. Lifelines: Biology beyond determinism. Oxford: Oxford University Press, 1998.

43 Kluger R. Ashes to ashes: America's hundred-year cigarette war, the public health, and the unabashed triumph of Philip Morris. New York: Alfred A Knopf, 1996.

44 Washington HA. Burning love: big tobacco takes aim at LGBT youths. Am J Public Health 2002;92:1086-95.

45 Barker DJP. Mothers, babies, and health in later life. Edinburgh: Churchill Livingston, 1998.

46 Kuh D, Ben Shlomo Y, eds. A life course approach to chronic disease epidemiology. 2nd ed. New York: Oxford University Press, 2004.

47 Davey Smith G, ed. Health inequalities: lifecourse approaches. Bristol, UK: Policy Press, 2003.

48 Joint WHO/FAO Expert Consultation on Diet, Nutrition and the Prevention of Chronic Diseases. Diet, nutrition and the prevention of chronic diseases: report of a joint WHO/FAO expert consultation, WHO Technical Report Series 916. Geneva: World Health Organisation, 2003, http:// www.who.int/nut/documents/trs_916.pdf (accessed 25 Apr 2004).

49 Solomon CG, Manson JE. Obesity and mortality: a review of the epidemiologic data. Am J Clin Nutr 1997;66(suppl 4):1044-50S.

50 Rimm EB, Stampfer JM, Giovannucci E, et al. Body size and fat distribution as predictors of coronary heart disease among middle-aged and older US men. Am J Epidemiol 1995;141:1117-27.

51 Kempe CH, Silverman FN, Steele BF, et al. The battered-child syndrome. JAMA 1962;181:17-24.

52 Gordon L. Heroes of their own lives: the politics and history of family violence, Boston, 1880-1960. New York: Viking, 1988.

53 Ashby L. Endangered children: dependency, neglect and abuse in American history. New York: Twayne Publishers, Simon and Schuster Macmillan, 1997.

54 Krug E, Dahlberg L, Mercy J, et al. World report on violence and health. Geneva: World Health Organisation, 2002.

55 Rosenberg DA, Krugman RD. Epidemiology and outcome of child abuse. Annu Rev Med 1991;42:217-24.

56 Merrick J, Browne KD. Child abuse and neglect-a public health concern. Public Health Rev 1999;27:279-93.

57 Vartiainen E, Seppala T, Lillsunde $P$, et al. Validation of self reported smoking by serum cotinine measurement in a community based study. J Epidemiol Community Health 2002;56:167-70.

58 Caraballo RS, Giovino GA, Pechacek TF. Self-reported cigarette smoking vs serum cotinine among U.S. adolescents. Nicotine Tob Res 2004;6:19-25.

59 Niedhammer I, Bugel I, Bonenfant S, et al. Validity of self-reported weight and height in the French GAZEL cohort. Int J Obes Relat Metab Disord 2000;24:1111-18.

60 Nieto-Garcia FJ, Bush TL, Keyl PM. Body mass definitions of obesity: sensitivity and specificity using self-reported weight and height. Epidemiology 1990;1:146-52.

61 Hebert JR, Ebbeling CB, Matthews CE, et al. Systematic errors in middle-aged women's estimates of energy intake: comparing three self-report measures to total energy expenditure from doubly labeled water. Ann Epidemiol 2002; 12:577-6.

62 Krieger N, Fee E. Measuring social inequalities in health in the United States: an historical review, 1900-1950. Int J Health Serv 1996;26:391-418.

63 Sydenstricker E. Health and the Depression. Milbank Mem Fund Q 1934; 12:273-80

64 Collins SD, Tibbitts C. Research memorandum on social aspects of health in the Depression. New York: Social Science Research Council, Bulletin 36, 1937.

65 United States Public Health Service, Division of Public Health Methods. The National Health Survey, 1935-1936. Washington, DC: Federal Security Agency, Public Health Service, 1951

66 US Department of Health, Education, and Welfare. Origin and program of the US National Health Survey, a description of the developments leading to the enaction of the National Health Survey Act, and a statement of the policies and initial program of the survey. Washington, DC: Department of Health, Education, and Welfare, 1958

67 Krieger N. Discrimination and health. In: Berkman L, Kawachi I, eds. Social epidemiology. New York: Oxford University Press, 2000:36-75.

68 Krieger N, Sidney S. Racial discrimination and blood pressure: The CARDIA study of young black and white adults. Am J Public Health 1996;86:1370-8.

69 Mustillo S, Krieger N, Gunderson E, et al. Self-reported experiences of racial discrimination and black-white differences in preterm and low-birth weight delivery: the CARDIA study. Am J Public Health 2004;94:2125-31.

70 Davey Smith G, Ebrahim S. Data dredging, bias, or confounding. BM 2002;325:1437-8.

71 Elliott P. High blood pressure in the community. In: Bulpitt CJ, ed. Handbook of hypertension. Vol 20. Epidemiology of hypertension. Amsterdam: Elsevier, 2000:1-18. 
72 Lopes AA, Port FK. The low birth weight hypothesis as a plausible explanation for the black/white differences in hypertension, non-insulin-dependent diabetes, and end-stage renal disease. Am J Kidney Dis 1995;25:350-6.

73 Lackland DT, Egan BM, Ferguson PL. Low birth weight as a risk factor for hypertension. J Clin Hypertens 2003:5:133-6.

74 Hardy R, Kuh D, Langenberg C, et al. Birthweight, childhood social class, and change in adult blood pressure in the 1946 British birth cohort. Lancet 2003;362:1 178-83

75 Falkner B, Hulman S, Kushner H. Birth weight versus childhood growth as determinants of adult blood pressure. Hypertension 1998;31:145-50

76 Vupputuri S, He J, Munter P, et al. Blood lead level is associated with elevated blood pressure in blacks. Hypertension 2003;41:463-8.

77 Glenn BS, Stewart WF, Links JM, et al. The longitudinal association of lead with blood pressure. Epidemiology 2003;14:30-6.

78 Frumkin H, Walker ED, Friedman-Jiménez G. Minority workers and communities. Occup Med 1999; 14:495-517.

79 Krieger N. Racial and gender discrimination: risk factors for high blood pressure? Soc Sci Med 1990;30:1273-81.

80 Williams DR, Neighbors $\mathrm{H}$. Racism, discrimination and hypertension: evidence and needed research. Ethn Dis 2001;11:800-16.

81 Rosenberg L. Hormone replacement therapy: the need for reconsideration. Am J Public Health 1993;83:1670-3.

82 Seaman B. The greatest experiment ever performed on women: exploding the estrogen myth. New York: Hyperion, 2003.
83 Beral V, Banks $E$, Reeves $G$. Evidence from randomised trials on the long-term effects of hormone replacement therapy. Lancet 2002;360:942-4.

84 Enserink M. The vanishing promise of hormone replacement. Science 2002;297:325-6.

85 US Preventive Services Task Force. Postmenopausal hormone replacement therapy for the primary prevention of chronic conditions: recommendations and rationale. Am J Nurs 2003;103:83-91.

86 Rosenberg L, Shapiro S, Kaufman DW, et al. Patterns and determinants of conjugated estrogen use. Am J Epidemiol 1979;109:676-86.

87 Petitti DB, Perman JA, Sidney S. Estrogens and mortality. N Engl J Med $1986: 315: 131-2$

88 Kuh D, Hardy R, Wadsworth M. Social and behavioural influences on the uptake of hormone replacement therapy among younger women. B J Obstet Gynaecol 2000;107:731-9.

89 Krieger N. Postmenopausal hormone therapy. (Letter). N Engl J Med 2003;348:2363.

90 Grodstein F, Clarkson TB, Manson JE. Understanding divergent data on posthormonal hormone therapy. N Engl J Med 2003; 348:645-50.

91 Turgeon JL, McDonnell, Martin KA, et al. Hormone therapy: physiological complexity belies therapeutic simplicity. Science 2004;304: 1269-73.

92 Krieger N. Commentary: society, biology, and the logic of socia epidemiology. Int J Epidemiol 2001;30:44-6.

\section{THE JECH GALLERY}

\section{Afghanistan is back in the international public health community}

A

fter more than 20 years of war, it was a really great pleasure for participants of the 2nd international conference on local and regional health programmes, held in Quebec (Canada) in October 2004, to listen to a paper presented by an Afghan health professional (Shakir Sahibullah, MD from Aide Médicale Internationale). . ${ }^{1}$ Firstly, it was an opportunity to share our collaborative experiences on health financing studies with colleagues from everywhere, as I have been working in Afghanistan since 1996 and in collaboration with the speaker since $2001 .^{2}$ Lastly, but not least, as more than 40 countries were present it was an important occasion, even if aid donors are still miserly, ${ }^{3}$ to show that Afghanistan is back in the international public health scientific community.

Valery Ridde Laval Univeristy. Medical Faculty, Pavillon de I'Est Québec, Canada G1K 7P4; valery.ridde.1@ulaval.ca

Funding: thanks to the conference sponsors for the bursary to Dr Sahibullah Shakir.

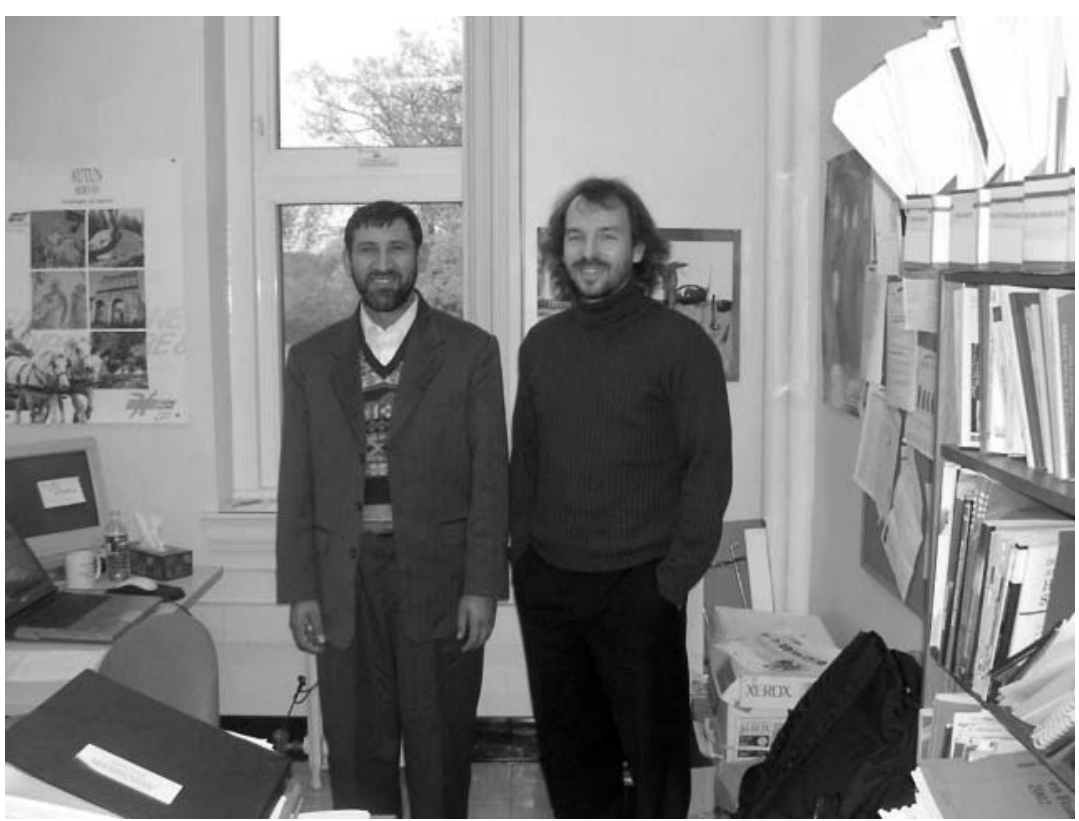

\section{REFERENCES}

1 Shakir S, Ridde V, Bonhoure $\mathrm{P}$, et al. How to increase the access of health care in Afghanistan with a participative evaluation and contextual (local) evidence. 2nd International conference on local and regional health programmes, Quebec, Canada, Oct 2004. http://

www.colloquequebec2004.com

2 Ridde V. Seeds against malnutrition in

Afghanistan: an experience in participative performance evaluation training. In: Mathison S, ed. Encylopedia of evaluation. Thousand Oaks: Sage, 2004:433-4.

3 Khabir A. Health and money in Afghanistan.

Lancet 2004;364:1301-2. 